\title{
Functional Scenarios for the Revitalization of the Port of Pelotas, State of Rio Grande do Sul, Brazil
}

\author{
MARCELO VINÍCIUS DE LA ROCHA DOMINGUES \\ Universidade Federal do Rio Grande \\ LETÍCIA DE MAGALHÃES BANDEIRA \\ Universidade Federal do Rio Grande
}

\begin{abstract}
This study outlines three functional scenarios for the Port of Pelotas, which is located in the center of the largest coastal lagoon system in the country, on the coastal plain of the State of Rio Grande do Sul, Brazil. It is aimed at guiding decision makers as to the planning of strategic actions for economic revitalization, whereas this Port, at present, has been the target of political and economic interests at local, regional and bi-national levels. The results achieved are summarized in a survey of its current functional status, in addition to the design of three future scenarios, based on functional alternatives. Therefore, the methods of exploratory research, SWOT analysis, prospecting scenarios, and semi-structured interviews with key actors for the research were used. Results show that, despite its current relative economic and functional stagnation, the Port of Pelotas is in a position to play a new and important role in the economic development recovery of the southern region of the State, as well as the integrated development of the Mirim Lagoon Basin through the bi-national Brazil-Uruguay waterway.

Keywords: Port revitalization; Brazil-Uruguay waterway; Coastal shipping.
\end{abstract}

\section{Cenários Funcionais para a Revitalização do Porto de Pelotas, Rio Grande do Sul, Brasil}

\section{Resumo}

O presente estudo teve por objetivo delinear três cenários funcionais para o Porto de Pelotas, localizado no centro do maior sistema lagunar costeiro do País, situado na Planície Costeira do Estado do Rio Grande do Sul, Brasil, com o intuito de nortear os tomadores de decisão quanto ao planejamento de ações estratégicas para sua revitalização econômica, considerando que este Porto, presentemente, vem sendo alvo de interesses políticoeconômicos em nível local, regional e bi-nacional. Os resultados alcançados se resumem em um levantamento da sua atual situação funcional, além do delineamento de três cenários 
futuros, baseados em alternativas funcionais estabelecidas para o mesmo. Para tanto, foram utilizadas as metodologias de pesquisa exploratória, além da análise SWOT, prospecção de cenários e entrevista semi-estruturada com atores chave para a pesquisa. Concluindo este artigo, constata-se que, apesar de sua atual relativa estagnação econômico-funcional, o Porto de Pelotas apresenta condições para desempenhar um novo e importante papel no processo de retomada do desenvolvimento econômico da metade sul do Rio Grande do Sul, bem como do desenvolvimento integrado da Bacia da Lagoa Mirim através da hidrovia bi-nacional Brasil-Uruguai.

Palavras-chave: Revitalização portuária; Hidrovia Brasil-Uruguai; Navegação de cabotagem.

\section{Escenarios Funcionales para la Revitalización del Puerto de Pelotas, Rio Grande do Sul, Brasil}

\section{Resumen}

Este estudio tuvo como objetivo delinear tres escenarios funcionales para el Puerto de Pelotas, situada en el centro del mayor sistema de laguna costera en el país, que se encuentra en la llanura costera del estado de Rio Grande do Sul, Brasil, con el fin de guiar a los tomadores de decisiones como la planificación de acciones estratégicas para la revitalizacióneconómica, mientras que este puerto, en la actualidad, ha sido el objetivo de los intereses políticos y económicos a nivel local, regional y binacional. Los resultados obtenidos se resumen en un estudio de su situación laboral actual, además del diseño de los tres escenarios futuros, en base a las alternativas funcionales establecidos por la misma. Por lo tanto, se utilizaron los métodos de investigación exploratoria, además del análisis SWOT, la prospección de escenarios y entrevistas semiestructuradas a actores clave para la investigación. Para concluir este artículo, parece que, a pesar de su estancamiento económico y funcional relativa actual, el Puerto de Pelotas está en condiciones de desempeñar un nuevo e importante papel en el proceso de recuperación del desarrollo económico de la mitad sur de Rio Grande do Sul, así como el desarrollo integral de la cuenca del lago Mirim por la vía acuática binacional entre Brasil y Uruguay.

Palabras clave: Revitalización Del Puerto; Vía fluvial entre Brasil y Uruguay; Navegación del cabotaje.

\section{Introduction}

The following analysis on the current process of economic and functional revitalization of the Port of Pelotas aims to give relevance to a recent perspective in the context of the Brazilian State, that is to potentiate the more intensive use of waterways in the country's transport matrix, as well as to make it feasible through partnerships with private economic actors, covering a time cut between 1940 and 2015.

With the exception of the Amazon, where water transport is dominant due to the presence not only of the largest rainforest, but also the largest river basin of the world, the State of Rio Grande do Sul, since its inception, has always used the largest coastal lagoon system in the country (the Patos and Mirim Lagoons) to integrate and leverage socio-economic development, especially during the nineteenth and early twentieth century.

In this period, besides the Port of Rio Grande, ports such as those of Pelotas and Porto Alegre flourished and later fell into decay, due in large part to the 
aggrandizement of the ships used from the 1970 s on. So the Port of Rio Grande was restricted to regional port primacy for its natural and operating conditions of deep water.

After four decades of absolute economic stagnation, the Port of Pelotas became again the focus of political and economic interests involving both local and regional levels, such as those linked to the bi-national integration of Brazil-Uruguay through the use of the Mirim Lagoon Basin as a means of transport for new freights generated in the Uruguayan territory.

Thus, the discussion on the economic and functional revitalization of the Port of Pelotas that emerges in this early twenty-first century is a relevant subject to the regional development of the State of Rio Grande do Sul. It seeks to reinsert it within the following cargo shipping context: on the one hand, the metropolitan area of Porto Alegre, the Port of Rio Grande, and the future fluvial-lacustrine Uruguayan Ports of Cebollatí and Tacuarí, through the use of large, modern barge system, with load capacities from 2.500 to $5.000 \mathrm{tpm}$; on the other hand, the ports of the Southeast, Northeast and North regions, for coastal shipping through the use of small Handy size class ships, with load capacities of around 10.000 to 39.000 tpm (UNCTAD, 2014).

Because it is a case study, comparative analysis do not fit in the scope of this research, neither with river ports of other States and Regions of Brazil, given its historical, geographical and economic characteristics; nor with river ports of other countries, either developed or developing ones, for the same reasons in addition to cultural and political factors.

\section{Port of Pelotas}

The Port of Pelotas is a fluvial and lacustrine port, located on the coastal plain of the State of Rio Grande do Sul, Brazil, on the banks of Patos Lagoon. More specifically, it is on the left bank of the São Gonçalo Channel, which connects the Patos and Mirim lagoons, which form the largest coastal lagoon system in Brazil, in the city of Pelotas, southern region of the State, latitude $31^{\circ} 47$ o S and longitude $52^{\circ}$ $206 \mathrm{~W}$, with a total area of 8.062.750.282,44 $\mathrm{ft}^{2}\left(749.054 .012 \mathrm{~m}^{2}\right)$ (Figure 1). It integrates the State's port complex, formed by the ports of Rio Grande (maritime), Porto Alegre, Pelotas and Cachoeira do Sul (inland), and the road-rail-waterway junction of Estrela, in Taquari River (ANTAQ, 2014). 
Figure 1. Map of location and delimitation of the Port of Pelotas.
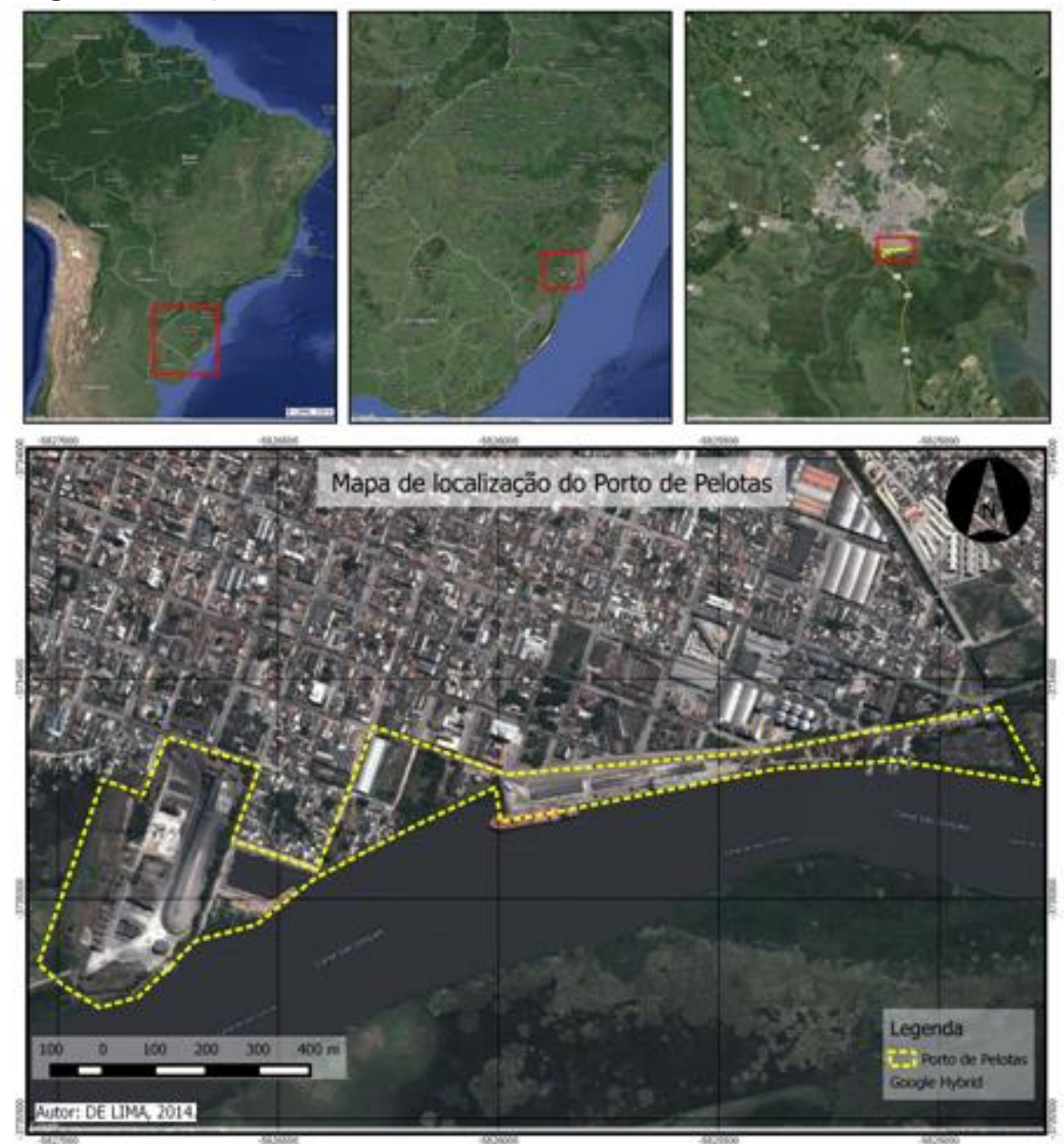

Source: DE LIMA, 2014.

The access channel to the Port is fluvial and lacustrine, including the major southeastern waterways of the Rio Grande do Sul, comprising the Patos Lagoon and the Mirim Lagoon, the São Gonçalo Channel and the Jaguarão River. By the São Gonçalo Channel, the Port of Pelotas is 7,59 miles distant from the waterway of the Patos Lagoon, having a draft of 17 feet (5,20 meters). From Lagoon Mirim, the Port is 36,71 miles $(58 \mathrm{~km})$ distant and the access channel has a draft of 8,2 feet $(2,50$ meters). Maritime access to the Port of Pelotas extends from the southern end of the Patos Lagoon, along 10,50 miles $(16,6 \mathrm{~km}$ ), with a width of 262,47 feet ( 80 meters) and depth of 19 feet (6 meters). Road access may occur through BR-293, BR-471, which intersects BR-116, this connecting to BR-293, 0,005 miles ( $8 \mathrm{~km})$ from the city of Pelotas. There is still the alternative of rail access by the railroad of America Latina Logística Malha Sul S.A. - ALL (SPH, 2012; ANTAQ, 2012).

Since 1997, the port is managed by the Superintendency of Ports and Waterways, a State Government Agence, together with the Port of Porto Alegre. The services performed by the Port of Pelotas set up the Inland Navigation characterized by a navigation performed in sheltered areas, such as lakes, ponds, bays, rivers, canals, dams, etc. The Port of Pelotas consists of two areas of public use, the Public Port itself and its river dock; a private port terminal, belonging to 
Cimpor - Cements of Brazil; and a cargo storage area for private use, the Jayme Power Terminal (Figure 2).

Figure 2. Terminals of the Port of Pelotas.

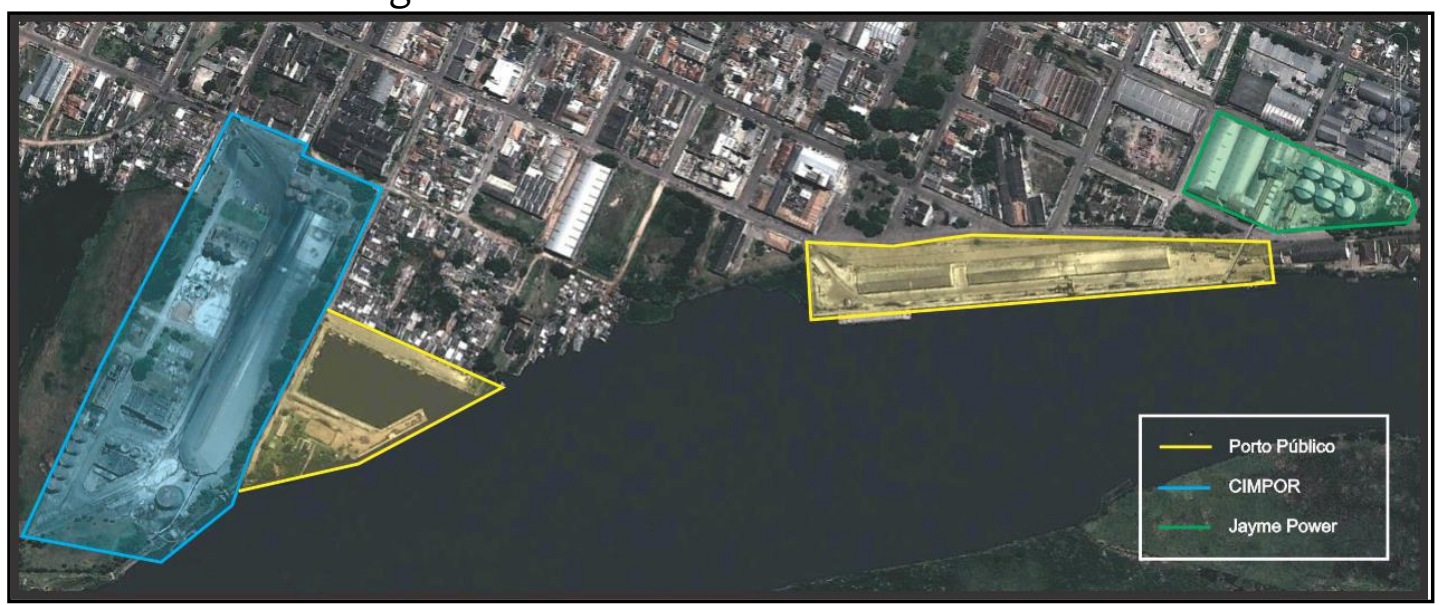

Source: SEP/PR, 2013, p. 36.

The Public Port is divided into a commercial wharf and a river dock. The commercial wharf has a length of 1640,42 feet (500 meters) and a depth of 17 feet (about 6 meters). It has three berths and three bonded warehouses for general cargo and bulk cargo, totaling $64.583,46 \mathrm{ft}^{2}\left(6.000 \mathrm{~m}^{2}\right)$, with a total capacity of $27.000 \mathrm{t}(\mathrm{SPH}, 2012)$. The river dock consists of a harbour with an internal pier length of approximately 1.312,34 feet (400 meters), and outside pier length of a little more than 262,47 feet ( 80 meters). It is currently only used for berthing recreational boats, as its dimensions and depth make it difficult for berthing vessels with current loading volumes.

The Jayme Power Terminal is intended for storage of grain, coal, petroleum coke, clinker, salt, fertilizer, and transportation of agricultural machinery. It consists of (overhead and underground) conveyor belts, hoppers, laboratory for grain analysis, and electronic weighing machine. Since it does not have a pier of its own, the commercial pier of the Public Port is used for its operations.

The Cimpor Terminal is for private use, with static storage capacity of 150.000 tons. It consists of a pier with two mooring dolphins, ten vertical silos, one horizontal silo, and nine storage tanks, which generally receives inputs such as clinker, petroleum coke, rice hulls, and limestone (SPH, 2012).

The Organized Port has its area divided into eight sub-areas, which are described in the following table (Table 1). Note that they are not yet constituted as official zoning areas for the expansion of the port activities. 
Table 1. Sub-areas of the Port of Pelotas.

\begin{tabular}{|c|c|c|c|c|}
\hline $\mathbf{N}^{\circ}$ & AREA & LOCATION & $\begin{array}{l}\text { TOTAL AREA/ } \\
\text { CAPACITY }\end{array}$ & DESTINATION \\
\hline 1 & $\begin{array}{l}\text { Police Country } \\
\text { House }\end{array}$ & $\begin{array}{l}\text { West from Pelotas } \\
\text { Stream }\end{array}$ & $\begin{array}{c}940.162,99 \mathrm{ft}^{2} \\
\left(87.344 \mathrm{~m}^{2}\right)\end{array}$ & $\begin{array}{c}\text { Area for the installation of multipurpose } \\
\text { terminals. }\end{array}$ \\
\hline 2 & CADEM & $\begin{array}{l}\text { east from the Pelotas } \\
\text { Swimming Club of } \\
\text { Regatas and west } \\
\text { from Pepino Stream }\end{array}$ & $\begin{array}{l}177.604,52 \mathrm{ft}^{2} \\
\left(16.500 \mathrm{~m}^{2}\right)\end{array}$ & $\begin{array}{l}\text { Ideal for shipping nonpolluting dry bulk } \\
\text { intrinsically for the proximity with small } \\
\text { residential area. Future container terminal. }\end{array}$ \\
\hline 3 & $\begin{array}{c}\text { Port } \\
\text { Administration }\end{array}$ & $\begin{array}{c}\text { west from the } \\
\text { Pelotas Swimming } \\
\text { Club of Regatas and } \\
\text { east from the } \\
\text { continuous port } \\
\text { wharf }\end{array}$ & $\begin{array}{l}94.722,41 \mathrm{ft}^{2} \\
\left(8.800 \mathrm{~m}^{2}\right)\end{array}$ & $\begin{array}{l}\text { Berthing area for the dredging industry } \\
\text { vessels and buoys and boat maintenance } \\
\text { services and marking equipment carried by } \\
\text { the ship repair sector. }\end{array}$ \\
\hline \multirow{5}{*}{4} & \multirow{5}{*}{$\begin{array}{l}\text { Continuous } \\
\text { Wharf }\end{array}$} & \multirow{5}{*}{$\begin{array}{l}\text { west from Port } \\
\text { Administration Area } \\
\text { and east from the } \\
\text { Garage and Old } \\
\text { Administration }\end{array}$} & $\begin{array}{l}17.222,26 \mathrm{ft}^{2} \\
\left(1.600 \mathrm{~m}^{2}\right)\end{array}$ & $\begin{array}{c}\text { Caixa D'água Yard - Berth 155: } \\
\text { Shipping of dry bulk, general cargo, and } \\
\text { heavy cargo. There is a conveyor belt } \\
\text { system coming from the Jayme Power } \\
\text { Terminal. }\end{array}$ \\
\hline & & & $\begin{array}{l}21.527,82 \mathrm{ft}^{2} \\
\left(2.000 \mathrm{~m}^{2}\right)\end{array}$ & $\begin{array}{l}\text { Warehouse } 3 \text { - Berth 101: } \\
\text { Shipping of dry bulk, unitized or not, with } \\
\text { inside storage area. }\end{array}$ \\
\hline & & & $\begin{array}{l}21.527,82 \mathrm{ft}^{2} \\
\left(2.000 \mathrm{~m}^{2}\right)\end{array}$ & $\begin{array}{l}\text { Warehouse } 2 \text { - Berth 102: Shipping of dry } \\
\text { bulk, unitized or not, with inside storage } \\
\text { area. It is the main area to use because of } \\
\text { the electric crane location. }\end{array}$ \\
\hline & & & $\begin{array}{l}21.527,82 \mathrm{ft}^{2} \\
\left(2.000 \mathrm{~m}^{2}\right)\end{array}$ & $\begin{array}{l}\text { Warehouse } 1 \text { - Berth 103: } \\
\text { Shipping of dry bulk, unitized or not, with } \\
\text { inside storage area. }\end{array}$ \\
\hline & & & $\begin{array}{l}29.062,56 \mathrm{ft}^{2} \\
\left(2.700 \mathrm{~m}^{2}\right)\end{array}$ & $\begin{array}{c}\text { Balance Yard - Berth 981: } \\
\text { Shipping of dry bulk, unitized or not, } \\
\text { general cargo, heavy cargo, and other yard } \\
\text { operations. }\end{array}$ \\
\hline 5 & $\begin{array}{l}\text { Garage and Old } \\
\text { Administration }\end{array}$ & $\begin{array}{l}\text { west from } \\
\text { Continuous Wharf } \\
\text { and east from the old } \\
\text { CIBRAZEM land area }\end{array}$ & $\begin{array}{l}71.041,81 \mathrm{ft}^{2} \\
\left(6.600 \mathrm{~m}^{2}\right)\end{array}$ & $\begin{array}{l}\text { Area for the storage and maintenance of } \\
\text { port vehicles and other yard operations. }\end{array}$ \\
\hline 6 & CIBRAZEM & $\begin{array}{l}\text { west from the Garage } \\
\text { and east from João } \\
\text { Pessoa street }\end{array}$ & $\begin{array}{l}87.402,95 \mathrm{ft}^{2} \\
\left(8.120 \mathrm{~m}^{2}\right)\end{array}$ & $\begin{array}{l}\text { Area for the installation of multipurpose } \\
\text { terminals. }\end{array}$ \\
\hline 7 & Fluvial Dock & $\begin{array}{l}\text { west from Bento } \\
\text { Martins street and } \\
\text { east from Alberto } \\
\text { Rosa street }\end{array}$ & - & $\begin{array}{l}\text { Area for the maintenance, boarding and } \\
\text { landing of small vessels. }\end{array}$ \\
\hline 8 & $\begin{array}{l}\text { CIMPOR } \\
\text { Terminal }\end{array}$ & $\begin{array}{l}\text { west from Fluvial } \\
\text { Dock and east Santa } \\
\text { Cruz street }\end{array}$ & $\begin{array}{l}\text { static storage } \\
\text { capacity of } \\
150.000 \mathrm{t}\end{array}$ & $\begin{array}{l}\text { Area for the storage of clinker, } \\
\text { petroleum coke, rice hulls, and other } \\
\text { inputs. }\end{array}$ \\
\hline
\end{tabular}

Source: adapted from SEP/PR, 2013.

Areas listed in Table 1 are shown in Figure 3. 
Figure 3. Sub-areas of the Port of Pelotas.

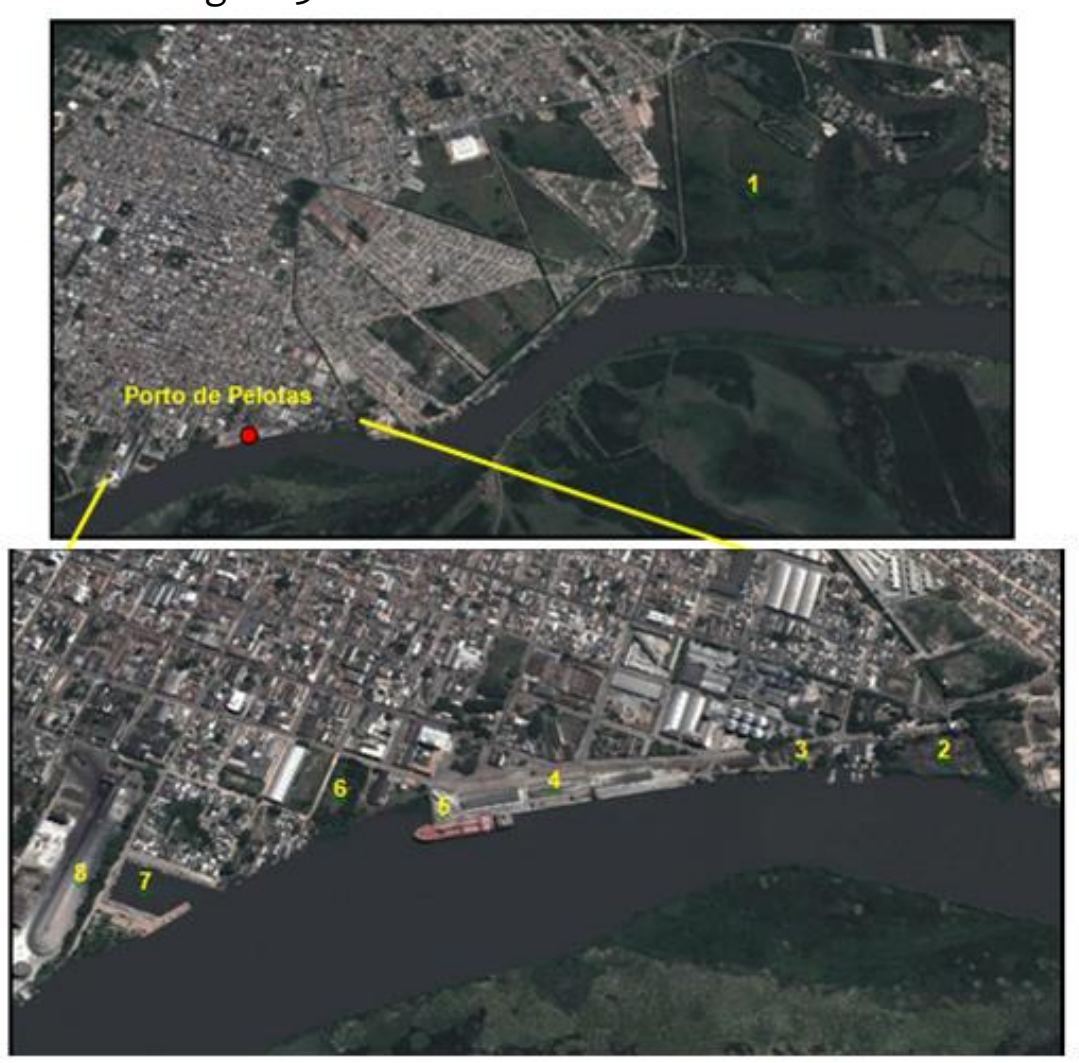

Source: BANDEIRA, 2014, p. 67.

An important feature to be highlighted in this development context is that the Port of Pelotas has a bonded port status, granted by the Internal Revenue Service of Brazil, which means it is authorized to operate foreign trade, thus allowing it to play an important role in generating employment and income, as well as in the reduction of logistics costs for export and import companies in the South Region (SPH, 2012).

As for cargo shipping, Graphic 1 shows the evolution at the Port of Pelotas in the period of 1940-2015.

Graphic 1. Evolution of load shipping at the Port of Pelotas (1940-2015).

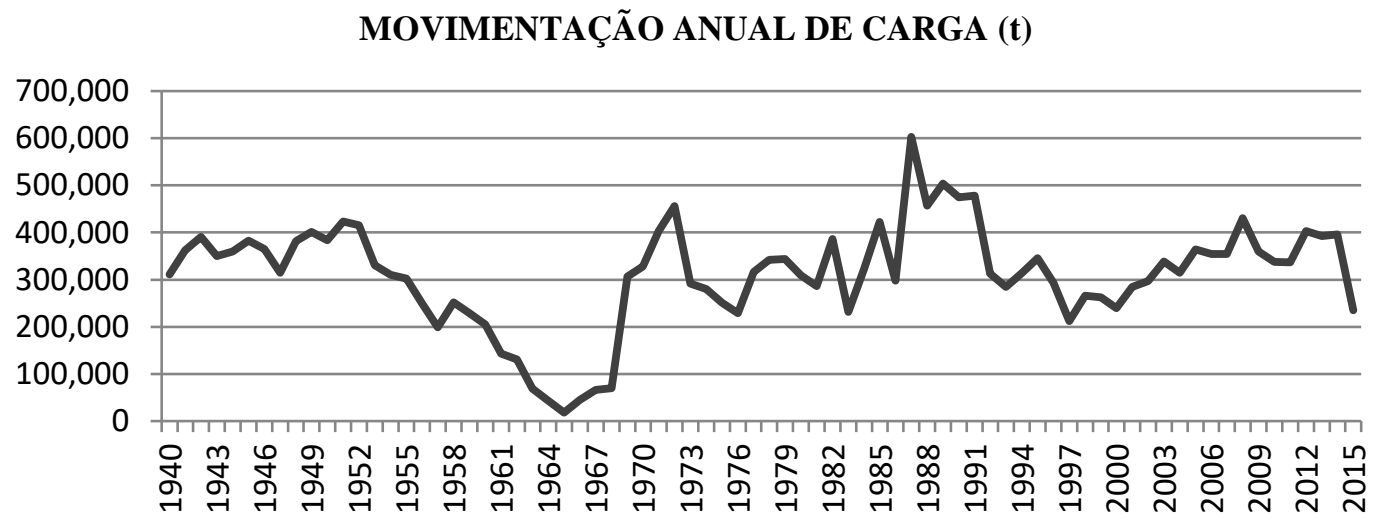

Source: SPH/PELOTAS, 2016. 
Historically, between 1940 - the year in which the Port of Pelotas became operational - and late 1960s, it had cargo shipping activities - wheat imports from Argentina and costal shipping import. However, from the 1960 s on, such operations stopped due to several factors, currently remaining only small cargo shipping, basically landing of goods for the local agricultural production demand - fertilizers and shipments related primarily to raw material for cement production - the clinker. With regard to inland waterway transport, traffic between Porto Alegre and Rio Grande, existing in the 1950s, virtually disappeared as from the end of the 1960s, while the exchange with other ports of Patos and Mirim lagoons became insignificant from the 1970 (Campêlo and Duhá, 2009; SPH/Pelotas, 2016).

Therefore, it is clear that unfortunately over the years port activities carried out by the Port of Pelotas were relatively abandoned due to many reasons, among which stands out the lack of planning and poor management by the Government. However, considering that today this port has been the target of state-level and binational interests to livens it economically, there are expectations to resume its importance as a commercial port for coastal cargo shipping, fueled by rice export to the Southeast, North and Northeast Regions of the country. It also has possibilities of becoming an industrial auxiliary support platform for the Port of Rio Grande and the future Port of São José do Norte, situated across from the Port of Rio Grande. Moreover, it has an important social role through its historical and cultural heritage within the city of Pelotas, as well as presents conditions to become an important waterway between Brazil and Uruguay.

In a scenario where all these features become converged at the Port of Pelotas, it is essential to establish strategies, through the assessment of current situation and the proposition of future scenarios, so that the reoccupation of the port area coastal region is carried out in an ordered and planned way, also avoiding potential future land use conflicts. In order to assist decision-makers in planning the strategic actions for the development of the Port of Pelotas, this study outlines three scenarios: Possible, Achievable, and Desirable. According to Souza (2004); Marcial \& Grumbach (2008), building scenarios means studying the various future possibilities, simulating reality developments, and preparing organizations for any of them, or even creating conditions for modifying their occurrence probability or minimizing their effects, without the concern of quantifying probability and without the limitation of identifying a unique possibility of future, seen as the more plausible trend. The scenario planning affects the perception of reality and expands it, thus providing a necessary variety to seeing and perceiving the outside world beyond the existing organizational standards.

\section{Metodology}

The research for this article may be defined as exploratory and includes the use of semi-structured interviews, document research, SWOT analysis an prospective scenarios technique as research tools.

Exploratory research is conducted on a subject with little or no previous study. In this respect, it is worth noting the almost complete absence of studies on the Port of Pelotas, which are restricted basically to master's dissertations in the last five years. The goal of such research is to look for patterns, ideas or hypotheses. 
The techniques typically used for exploratory research are case studies, observations and historical analysis, and results generally provide qualitative or quantitative data (Gil, 2002). According to Severino (2007), documentary research has not only printed documents as a source, but also documents in a broader sense, such as newspapers, photographs, films, recordings, legal and technical documents, etc., i.e. sources that do not have their contents analyzed, which serve as raw material for the researcher, who shall develop its interpretation and analysis.

Regarding interviews, they are held as a face-to-face conversation, in a systematic way, and may result in privileged and necessary information that may not be found through documentary research. According to Roesch (2009), semistructured interview is used so that the researcher can identify and understand the interviewee's perspective. The interviews for this study were applied to the Head of Division of the Port of Pelotas, Darci José Martins Cunha - Agronomist, responsible for managing the administrative area of the Port of Pelotas; the Infrastructure Analyst of the Ministry of Transport, Otavio Augusto dos Santos Kosby - Civil Engineer; and the Clerk of Secretary of ports and waterways -SPH/Pelotas, Cleomar Pereira Ribeiro, in order to explore more deeply port issues and outline the development expectations for possible activities to be performed by the Port of Pelotas. The interviews gave subsidy for the design of scenarios for the Port of Pelotas, objective proposed herein.

SWOT analysis, another instrument used in this study, is also a management tool and can be adapted to any management segment, either business or environmental. It is the study of the internal reality of an organization, identifying their strengths and weaknesses, as well as studying the opportunities and threats from the external environment to the organization. This type of analysis is crucial to create strategic actions in times of uncertainty, since it allows the recognition of favorable and unfavorable factors within the environment, in addition to situating the organization in its real context, supporting the construction of scenarios that portray the reality of the organization (Cruz, 2010).

Regarding the methodology of scenarios, Marcial \& Grumbach (2008) define it as a way to forecast the external and internal environmental situation of an organization to a particular future time is used gererally for the purpose of formulating a strategic plan. According to the authors, the methodology of scenarios plus the SWOT analysis are considered two of the most important environmental analysis tools to determine organizational strategies in uncertain and turbulent environments. For this study, the scenarios classification established by Marcial \& Grumbach (2008) were chosen, because such scenarios are more objective and consistent with the reality of the object of study, as well as with the claims for it, which may enable the port organization to reduce uncertainties and guide managers on how to move to the best outlined future.

\section{Results}

The following discussion is presented in three parts. The first exposes the SWOT analysis of the Port of Pelotas, based on its natural and functional characteristics. The second outlines four functional alternatives to the studied port, based on projects already under negotiation for Pelotas. Finally, the third part 
outlines three types of scenarios for the Port of Pelotas, based on functional typologies that could be carried out until 2025.

\section{SWOT Analysis of the Port of Pelotas}

The SWOT $^{1}$ analysis presented below (Table 2) is intended to highlight the key attributes related to the internal and external environments of the Port of Pelotas.

Table 2. SWOT matrix of the Port of Pelotas

\begin{tabular}{|c|c|c|}
\hline \multirow{8}{*}{ 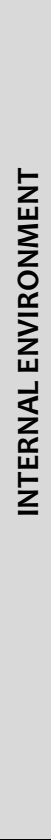 } & STRENGTHS & WEAKNESSES \\
\hline & $\begin{array}{l}\text { Good condition of infrastructure and } \\
\text { storage facilities }\end{array}$ & $\begin{array}{c}\text { Wharf depth of only six meters restricts } \\
\text { the size of vessels that could enter the } \\
\text { Port }\end{array}$ \\
\hline & $\begin{array}{l}\text { Reasonable potential capacity of } \\
\text { storage facilities }\end{array}$ & $\begin{array}{l}\text { Old Port equipment (shipping } \\
\text { conducted with board cranes and direct } \\
\text { landing) }\end{array}$ \\
\hline & $\begin{array}{l}\text { High availability for occupation of } \\
\text { berths and warehouses }\end{array}$ & Port located within urban area \\
\hline & $\begin{array}{l}\text { Possibility of expansion of the State of } \\
\text { Rio Grande do Sul, as well as of private } \\
\text { areas near the port }\end{array}$ & $\begin{array}{l}\text { It does not have its own equity income, } \\
\text { financially depending on the tariff } \\
\text { tables and on a Terminal of Private Use }\end{array}$ \\
\hline & $\begin{array}{l}\text { Bonded port, important for opening } \\
\text { to MERCOSUL }\end{array}$ & $\begin{array}{l}\text { It does not have its own team for } \\
\text { environmental management }\end{array}$ \\
\hline & $\begin{array}{l}\text { Wharf expansion possibility up to } 100 \\
\mathrm{~m} \text {, for handling containers }\end{array}$ & $\begin{array}{c}\text { Environmental licensing still under } \\
\text { development }\end{array}$ \\
\hline & $\begin{array}{l}\text { Important cargo shipping projects } \\
\text { under negotiation between the } \\
\text { Municipal, State and Federal } \\
\text { Governments }\end{array}$ & Low cargo shipping at the Public Port \\
\hline \multirow{8}{*}{ 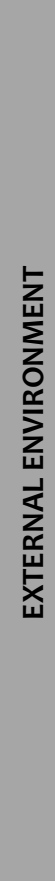 } & OPORTUNITIES & THREATS \\
\hline & $\begin{array}{l}\text { Port access road network in good } \\
\text { conditions }\end{array}$ & $\begin{array}{c}\text { Conflicting Port road access, through } \\
\text { the city }\end{array}$ \\
\hline & $\begin{array}{c}\text { Possibility of cargo shipping by the } \\
\text { Mirim Lagoon }\end{array}$ & $\begin{array}{l}\text { Urban traffic quite congested and many } \\
\text { intersections with traffic lights }\end{array}$ \\
\hline & $\begin{array}{c}\text { Dredging promotion on Brazilian ports } \\
\text { by the Federal Government, with the } \\
\text { possibility of } 25 \text { feet depth }\end{array}$ & $\begin{array}{c}\text { Inactive and incomplete railroad access } \\
\text { (remaining } 0,93 \text { miles }(1,5 \mathrm{~km}) \text { of } \\
\text { extension) }\end{array}$ \\
\hline & $\begin{array}{l}\text { Likely reactivation of the Patos } \\
\text { Lagoon waterway }\end{array}$ & $\begin{array}{l}\text { Unbearable competitive position in } \\
\text { relation to the Port of Rio Grande }\end{array}$ \\
\hline & $\begin{array}{l}\text { Implementation prospects of a Naval } \\
\text { Cluster at the Port of Pelotas }\end{array}$ & $\begin{array}{l}\text { Separatism between the municipalities } \\
\text { of Pelotas and Rio Grande }\end{array}$ \\
\hline & $\begin{array}{l}\text { Bottleneck at the port complex of Rio } \\
\text { Grande }\end{array}$ & \\
\hline & $\begin{array}{l}\text { Socio-cultural importance to the local } \\
\text { population of Pelotas, considered } \\
\text { Special Area of Cultural Interest } \\
\text { (AEIAC-ZPPC) by the Municipal Master } \\
\text { Plan }\end{array}$ & $\begin{array}{l}\text { Both channel margins are Protected } \\
\qquad \text { Areas }^{2}\end{array}$ \\
\hline
\end{tabular}

${ }^{1}$ Compiled by the authors (exclusively bibliographic data).

2 According to the National System of Conservation Units (Law 9.985/2000). 
From this analysis, the current situation of the Port of Pelotas can be understood so that other possible features, based on their actual performance possibilities, may be outlined.

Functional alternatives for the Port of Pelotas

Ports represent an important role in the national economy, since they develop numerous economic functions for the nation, such as commercial function, industrial function, logistic function, and also social function. Each port carries out its functions in accordance with natural characteristics and socioeconomic demands. As Porto (2007, p. 25) states, "port activity today is the result of a number of factors that makes it intensive, specialized, comprehensive and development fostering." 3

The Port of Pelotas, in particular, is going through a period of major negotiations with the federal, state and municipal governments, as well as the local and regional business community. Some projects are in an advanced state, others are still incipient. Among the prospective projects, only one, if effected, will make the Port of Pelotas as big as the Port of Porto Alegre, in terms of cargo shipping (Cunha, 2013). Projects under negotiation - arising from information collected interviews with some stakeholders for this study - were divided according to alternative functional types to be performed by the Port of Pelotas in the coming years, namely: commercial, logistics, industrial, and social functions.

\section{Commercial Function}

Considering its privileged position, as a southern terminal of river and lake links, located in a key point of railway and road transportation, the Port of Pelotas can render great service to the region. Thus, coastal shipping must ship in Pelotas cargo destined to the Brazilian coast, since this port offers optimum conditions to traffic, to ensure greater speed and economy in additional freight, which is the most satisfying of regional interests.

Today the Port of Pelotas can fulfill its expectations to resume its importance as a river port, boosted by the export of grain and wood products, for example, to the Southeast, North and Northeast regions of the country (Figure 4). 
Figure 4. Map showing the Commercial Function of the Port of Pelotas

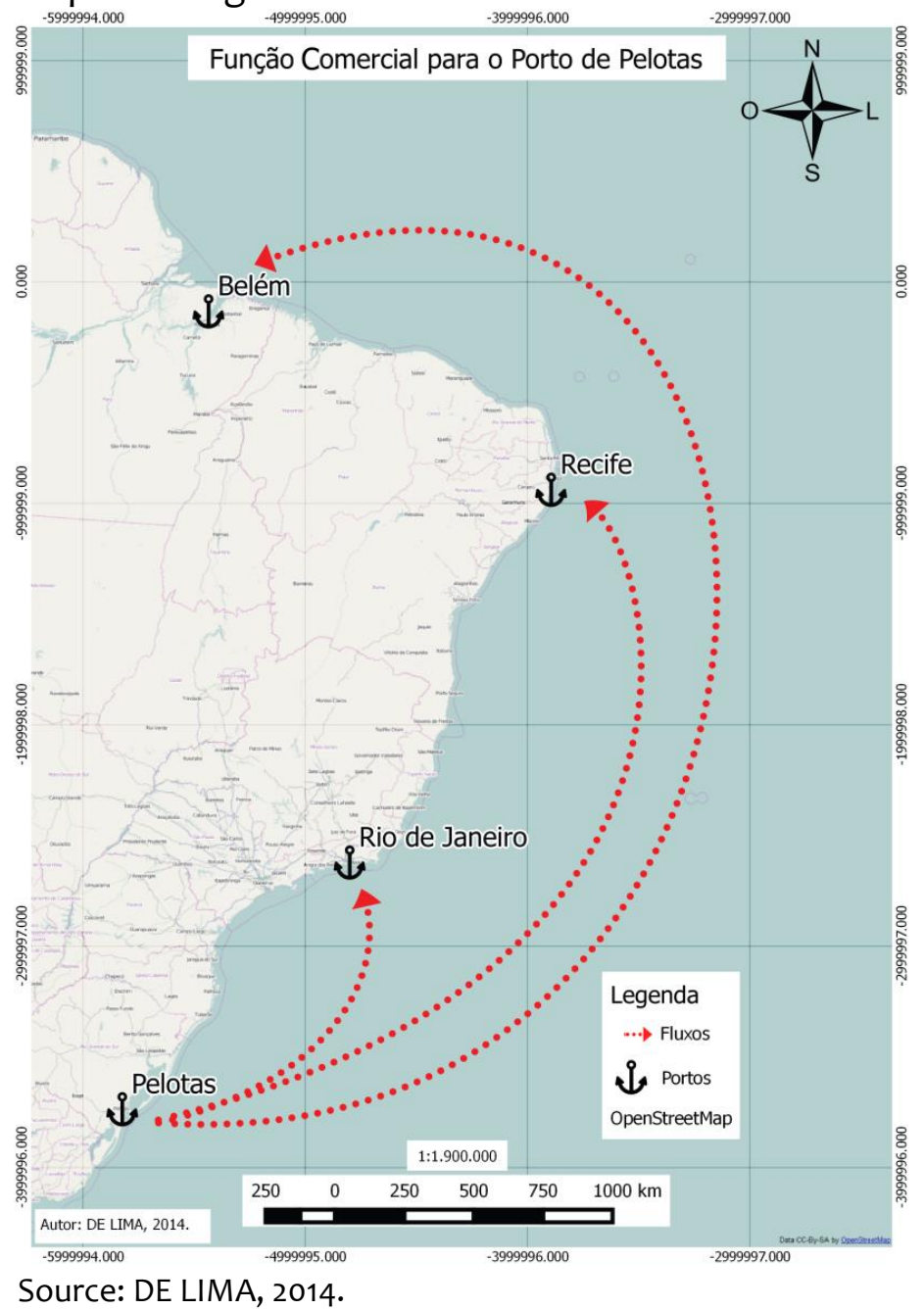

Some of the projects described in the interviews may be inserted in this proposal to leverage the commercial function of such port, among which were projects for shipping wood, gravel stone, soybeans, among others.

One of these projects is under negotiation with Riograndense Celulose - part of the CMPC group. It is a southern company in the eucalypts short fiber pulp international market. It has a factory in Guaíba municipality that invests in the cultivation of forests as a sustainable raw materials supply source. The project expects to move 1,2 million tons of eucalyptus logs to Guaíba. The logs from various cities of the State will leave Pelotas in barges - boats requiring shallow draft heading to Guaíba, where they will be transformed into pulp and sent to the Port of Rio Grande for exportation. The required structure of the Port of Pelotas for the realization of this project will be 9 hectares of Port area, in addition to wharf structure adequacy and staff improvement. The project was estimated for the first half of 2016, and the eucalyptus is ready for cutting since the end of 2014.

Another cited project intends to ship, also by barges, 250.000 tons of gravel stone from the surroundings of Cascata - 5 th district of Pelotas -to São José do Norte. For this project, the Port of Pelotas is ready to operate, with the required depth draft, as well as proper pier structure and equipment. To the access road 
should still be improved for this project, but this will not prevent the beginning of activities, which expected to start in 2016.

Another project under negotiation, also expected to be achieved in 2016, plans to ship 80.000 tons of soybeans produced in the Port of Rio Grande, through barge, for transshipment in larger vessels and export. The current structure of the Port of Pelotas is ready to meet the estimated demand for this project. There is also prospects for shipping other sorts of cargo in the Port of Pelotas, such as rice, malt and containers (SEP/PR, 2013).

Rice is a product that should be highlighted as a potential cargo to the Port of Pelotas, for Rio Grande do Sul is generally the Brazilian State showing the largest rice production, with figures of $8.069,903$ tons of rice in 2012/13 crop, corresponding to $68 \%$ of national production. In the 2013 season, harvested area amounted to 1,08 million hectares, approximately $45 \%$ of all harvested area in Brazil, which makes the southern State a potential exporter of rice to the world (IRGA, 2013). Almost half of the total rice shipped in Rio Grande in the year 2012 - 480.000 tons. - could have been shipped through Pelotas (SEP/PR, 2013).

The containerable cargo for shipment, such as rice and other general cargo, and for landing, as several general load - could be handled at the Port of Pelotas, supplying business ventures of the city, which would unburden the activities of the Port of Rio Grande, and mainly take these cargo from road transportation. Currently, many containers leave the Pelotas region via highway to the Port of Rio Grande, especially for rice, which are benefitted in Pelotas and taken in containers to Rio Grande, where they are loaded on coastal vessels. About 1.500 rice containers are transported via highway every 45 days from Pelotas to Rio Grande for coastal shipping.

An examination of the current fleet of coastal container ships shows that nine of the eighteen ships engaged in this type of navigation are less than 656,168 feet (200 meters) long, which would make possible, with the dredging of the channel, a partial load of its capacity at the Port of Pelotas (SEP/PR, 2013). In 2012, about 1.000.000 tons of bulk rice were exported through the Port of Rio Grande. For this, 83 shipments were made in vessels with average length of 155 meters - less than the authorized length for the Port of Pelotas, 656,17 feet (200 meters) - of which 11 have left the port of Rio Grande in draft less than 23 feet deep, so they could also operated through Pelotas. Moreover, in most of the other 72 moorings, ships could have been partially loaded at the Port of Pelotas and have their cargo completed in Rio Grande. Therefore, a draft of 25 feet would allow a stopover in Pelotas to meet rice demand, without considering other cargo that could benefit by such stopover. With the dredging of the channel, 58,7 tons of containers are provided for coastal shipping in the Port of Pelotas in 2016, reaching up to 117.500 in 2020, with an estimated average annual growth of 5,2\% (SEP/PR, 2013).

Another featured product is malt, whose production is concentrated in the southern states, and of the four Brazilian malt producers two are located in Rio Grande do Sul, one in Porto Alegre and the other in Passo Fundo. However, the domestic production does not meet domestic demand, the difference being imported mainly from Uruguay and Argentina (EMBRAPA, 2012). A survey carried out for this product indicates a demand of 100 tons in 2016 in the Port of Pelotas, with an increasing average annual rate equivalent to 3,1\% (SEP/PR, 2013). 
However, for the commercial economic viability of the Port of Pelotas to come into effect, it is necessary to organize it into structural and operational levels, appropriate to the current demands of water transportation. Moreover, according to Pereira (2000), it is crucial to redirect entrepreneurial mindset to this type of transport, since the logistics culture is focused on road transport; and encourage enterprises in the South Region with the potential flow of products to invest in this type of transport. It is essential, therefore, that the municipal administration, together with the State and Federal Governments, recover the entire waterway system in the region, a viable system which has been neglected.

\section{Logistics Function - Brazil-Uruguay waterway}

For a long time the Port of Pelotas served for the production flow of southern Rio Grande do Sul region, however, the water transport began to lose its importance with the construction of modern roads. Today, studies are being carried out to resume its logistical. After all, the waterway system, despite being slower than other modes, is cheaper, safer, and, therefore, more efficient.

The Patos and Mirim Lagoons, regarding the fluvial-lacustrine shipping, enable stimulating the regional economy and having greater economic integration with Uruguay. Their use may also be considered an alternative front to the current global competition, since transport quality influence the competitive position relative to other regions or even nations.

However, in order to stimulate the regional economy through the port system of Pelotas, an intensification of logistics is needed, particularly as to water transport, in search of greater integration among the MERCOSUL countries. The Port of Pelotas should seek to assume a new role for its own improvement and operational recovery, that is, the logistics function, in order to integrate the logistics route of regional and Uruguayan products, resuming its competitive operating capacity.

Thus, as analyzed by Pereira (2000), since 1999 the State Government of Rio Grande do Sul is seeking to promote proper conditions for cargo shipping with decreased costs, in order to improve not only the Port of Pelotas, but the entire waterway system of the State.

Currently there is a project under negotiation by the State and Federal Governments that proposes the building of a natural waterway of hydro-port-rail integration and exportation within MERCOSUL through the route of Mirim Lagoon São Gonçalo Channel - Patos Lagoon. This would enable cargo multimodal transport going from the State of São Paulo, through the State of Rio Grande do Sul to get to Uruguay, called Brazil-Uruguay Waterway or the MERCOSUL Waterway, an important leap in the quest for trade integration among MERCOSUL nations.

The MERCOSUL Waterway is located in the southeast basin and expands over 403,89 miles ( $650 \mathrm{~km}$ ). It consists of Jacuí and Taquari rivers, among others that connect to the Patos Lagoon across the Guaíba River, followed by São Gonçalo Channel and Lagoa Mirim, forming a major hub for trade between Brazil and Uruguay.

This project provides for the contemplation of cargo flow from Uruguay especially rice and wood - and the consumption of Uruguayan products in the State of Rio Grande do Sul. It is also an alternative to the BR-116 and BR-392, often 
congested. Moreover, it aims to consolidate an inner transport corridor connecting the poles of Montevideo and Sao Paulo.

The waterway is intended to give Uruguay a new flow option of its timber and cereal production by barges to carry transshipment in larger vessels at the Port of Pelotas or Rio Grande. As the Port of Rio Grande is aimed at higher capacity cargo ships, smaller ships would be directed to the Port of Pelotas, which has conditions to speed up the transfer. Thus, barges would come for transshipment in the Port of Pelotas and the ships would come out by coastal shipping to the Southeast, North and Northeast Regions of the country, or even abroad (Figure 5).

Figure 5. Map showing the Logistic Function of the Port of Pelotas

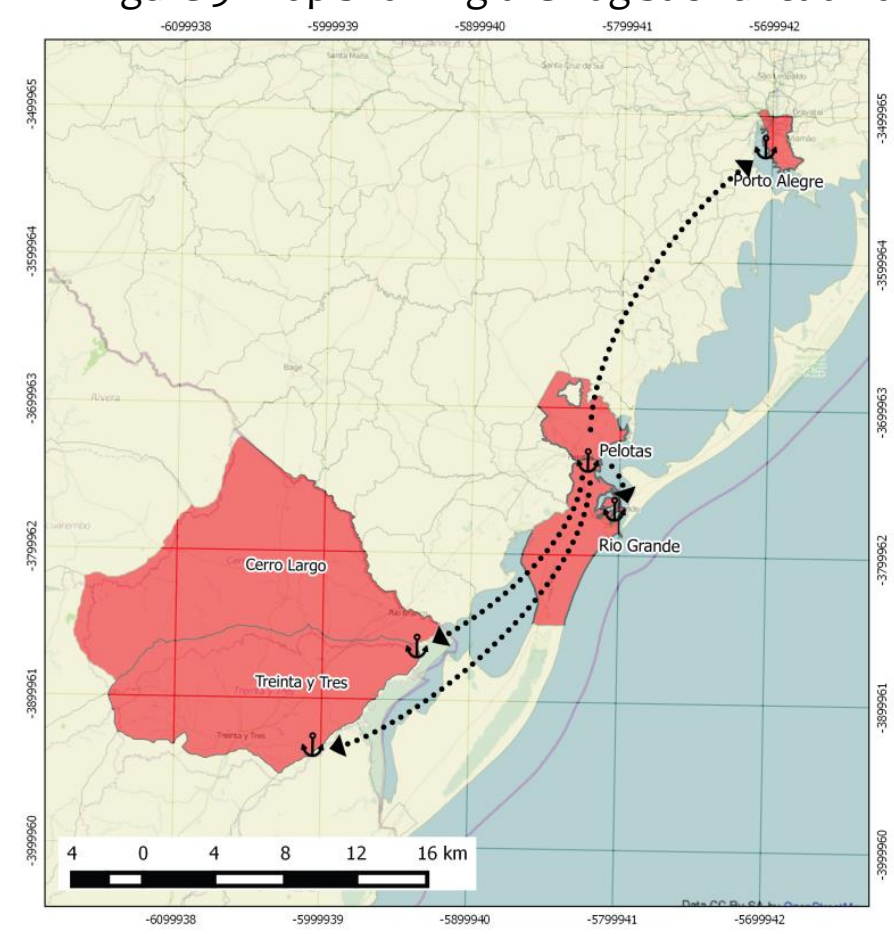

Função Logística para o Porto de Pelotas

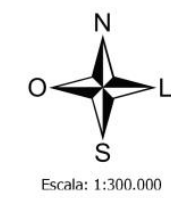

Legenda

Municípios e Departamentos

$\square$ Municípios e Departamentos em destaque

Outros

\&. Portos

$\rightarrow$ Fluxos

OpenStreetMap

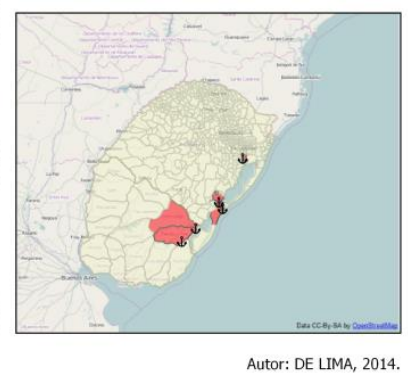

Source: DE LIMA, 2014

Uruguay is a country that stands out in the export of agricultural bulk (wheat, soybeans, sorghum, barley, maize and rice), as well as other products, mainly cement and wood, and its production has been growing in recent years, arousing interest on the flow of cargo between the two countries - Brazil and Uruguay, for export through the port of Rio Grande, by the Brazil-Uruguay Waterway.

Once the waterway is deployed, cargo shipping at the Brazilian side could be done through the Ports of Estrela, Cachoeira do Sul, Porto Alegre, Pelotas, Jaguarão, and Santa Vitória do Palmar, while at the Uruguayan side, lacking in port infrastructure, future terminals (to be built) would be used on the banks of Cebollati and Tacuarí rivers, tributaries of the Mirim Lagoon.

Tacuarí River is located on the border between the cities (departments) of Cerro Largo and Treinta y Tres, and Cebollatí River, further south, is located on the border between the cities (departments) of Treinta y Tres, Rocha and Lavalleja (Figure 6). 
Figure 6. Map of the proposed location for the Uruguayan ports.

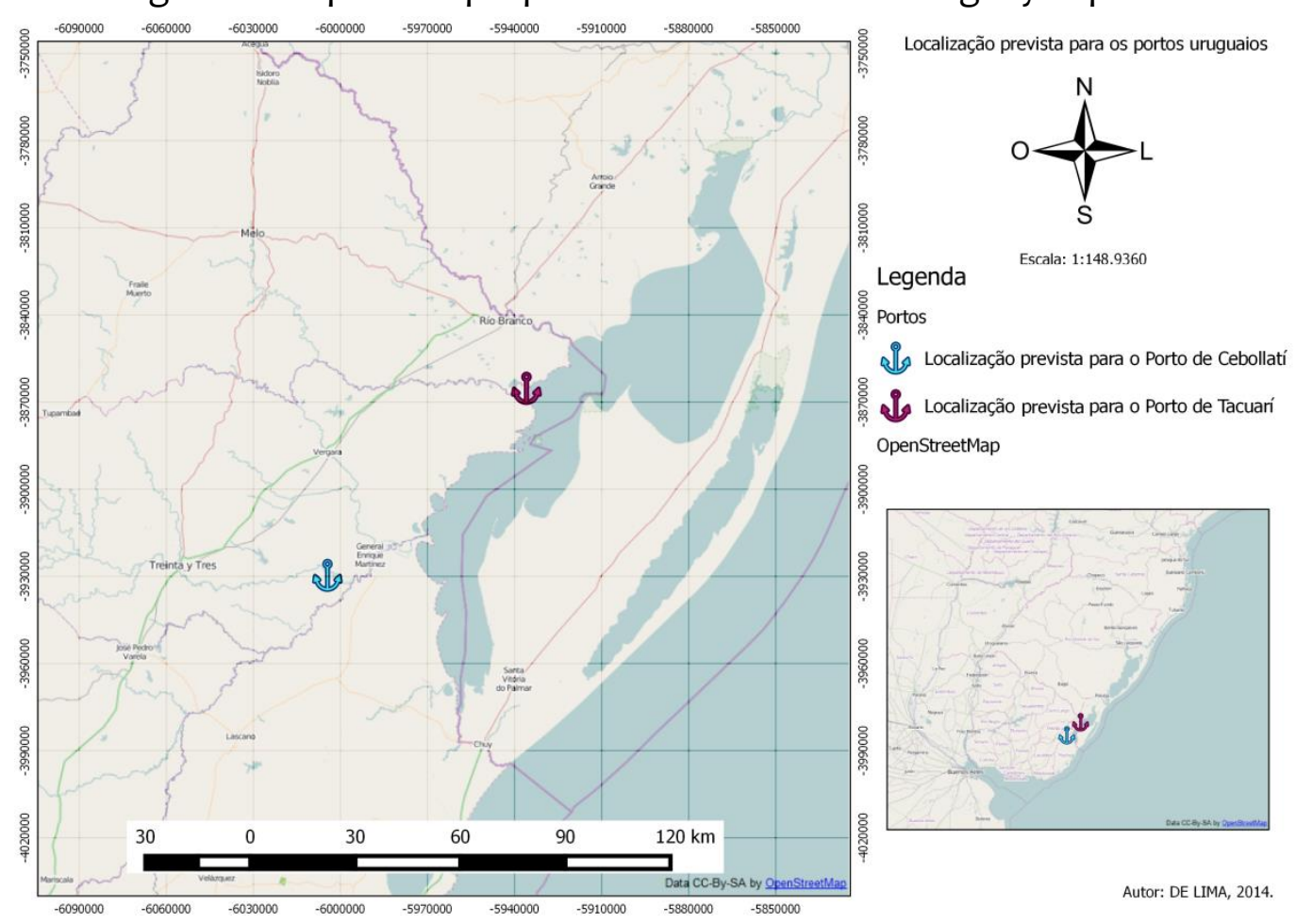

Source: DE LIMA, 2014.

The port terminal proposed to be built in Tacuarí River is located just 1,86 miles $(3 \mathrm{~km})$ from the river bar at the Mirim Lagoon. It will have two jetties for berthing and a cargo terminal with capacity of $250 \mathrm{t} / \mathrm{h}$, with static storage capacity of 40.000 tons. One of the terminals would be solely for grains and the other for further loads. The port terminal planned to be built in Cebollatí River will be located at a distance of 16,78 miles ( $27 \mathrm{~km}$ ) upstream of the river bar at the Mirim Lagoon. A first stage of the project is for bulk and palletized cargo, and a second stage provides the transport of wood chips, requiring facilities that would occupy 20 hectares and a capacity of 100 tons/hour. There is also the proposed construction of a third terminal for the transport of cement and derivatives (Fossati, 2013).

Fossati (2013) highlights a forecast, made by the Hydrographic Director of the Uruguayan Ministry of Transport to the newspaper El Diario, of an estimated export of around 300.000 tons per year in the first operation stage for each of the projected Uruguayan ports. Through execution of these Uruguayan designs, the transport of rice and soybean, as well as wood which use roads nowadays, could be made via Mirim Lagoon - Patos Lagoon, shipping large cargo quantities, since these cultures and Uruguayan cultivated forests are concentrated in the area of influence of the Mirim Lagoon.

Also according to Fossati (2013), the potential for cargo addressed to the Brazilian market, with the main products exported by Uruguay in 2012, shows a total of 2.533.918 tons of agricultural bulk - wheat, sorghum, barley, corn, and rice; 60.142 tons of wood industries, and 41.869 tons of Portland cement, totaling approximately 2,6 million tons of cargo. The flow of these products via waterway, influences even on their cost, through the cheapening of freight in relation to the 
Port of Montevideo, since the depth of the Port of Rio Grande is greater than that of Montevideo, allowing larger vessels to get in and European and the United States ports to be connected by a shorter distance, thus bringing shallow sea freight.

A further handling of rice through the Port of Pelotas could derive from the actualization of water transport, since paddy rice exported by Uruguay could be brought to improvement in Pelotas (SEP/PR, 2013).

Another highlighted Uruguayan product is the limestone, as near the city of Treinta y Tres there is a considerable number of calcareous deposits of very good quality and significant volume, characteristics that make its exploitation widely feasible. It is estimated that in a radius less than 27,96 miles $(45 \mathrm{~km})$ there is a total volume of 70 million tons of limestone distributed in various fields. If considered throughout the city (department) Treinta y Tres, there are reserves of tens of millions of tons more (CLM 2012 apud Fossati, 2013). This product is already included in a project prepared by the company Cementos Treinta $Y$ Tres SA by the "National Administration of Fuel, Alcohol and Cement" (Administración Nacional de Combustibles, Alcoholes y Portland- ANCAP), with estimated production capacity of 600.000 tons per year, and operating expectations within two years (Fossati , 2013).

Initially the projects planned for shipping cargo from Uruguay, (Fossati, 2013), are intended for those more sensitive as to the value of freight and which, by proximity, require the ports installed in the region. But this does not mean that with time other cargos might not be brought to these ports, generating an increase in the cargo shipping, in addition to the value added with the industrialization of these products. Along with cargo shipping routes, the Ministry of Tourism of Uruguay also aims to enable Fluvial Tourism routes as a result the Cebollati and Tacuari port terminals. However, even if the port project in Tacuarí River provides for a berthing pier for sports vessels, in a first stage, existing projects do not consider the possibility of passenger transport.

There may also be a passenger demand for the region of Pelotas through this waterway. After all, Pelotas offers interesting cultural attractions as it has been a stage for important historical passages, such as the Ragamuffin War, the Federalist Revolution, and the 1923 Revolution, as well as a prominent setting in beef jerky economic cycle in Rio Grande do Sul. In addition to this cultural tourism, the city offers other forms of tourism such as rural and natural tourism (SEP/PR, 2013). Thus, the potential for passenger transport must be considered in order to create an international tourist route along the lagoons, following international models of river tourism.

However, some limitations for river tourism in Pelotas should be brought up, as the increasing size of cruise ships, which would hardly reach the Port of Pelotas without an environmental intervention in the physical structure thereof; besides the fact that the city of Montevideo and other major cities of Uruguay constitute currently a competing route regarding tourism, as they are served by seagoing vessels. Thus, the passenger transport potential in the Port of Pelotas can be considered low, with long-term prospects only.

Therefore, the mentioned products and their cargo volumes are the ones that currently justify the economic viability of Brazil-Uruguay Waterway, and its project is already included in the Growth Acceleration Program of the Federal Government, with an investment forecast of $\mathrm{R} \$ 50$ million in 2016. According to the 
executive secretary of the Council for Economic and Social Development (Cdes/RS), Marcelo Danéris in an interview with the local newspaper Diário Popular, "the construction of the waterway is a former regional demand for the consolidation of an important alternative to logistics development of the State" (Project, 2013). The Study of Technical-Economic and Environmental Feasibility was recently concluded and its consolidation authorized.

For this scenario to become a reality, according to Cdes/RS, it is necessary to approach the stakeholders linked to water transportation governments of Uruguay and Brazil, the state government, municipalities and the private sector, thus promoting the sharing of relevant information to the project. Moreover, an integration with road and rail modes is fundamental to the proper functioning of the waterway, which is to intensify the urgency of the access improvements already weighed.

In this way, the different levels of power must pay urgent attention, focused on the potential of regional economic development, signaled by the logistics alternative under analysis, idealized by the construction project of the BrazilUruguay Waterway.

\section{Industrial Function}

As from the extinction of "Portobrás", in the 1990s, there was a substantial decrease in the economic performance of the Port of Pelotas. Therefore a decline of the industrial environment of the port area is characterized according to Poetsch (2002, p. 113) by the following economic, political and theoretical aspects: "a) the state industry crisis and virtually the depletion of traditional industries in Pelotas, responsible for the great commercial use of the port, irreversibly reduced the city's fluvial cargo flow; b) the increased price of shipping, from 1953 to 1960, seriously undermined the Port of Pelotas activities, further expanding the rise in prices; c) competition with the port of Rio Grande became inevitable; d) the lack of the access channel maintenance dredging to the Port of Pelotas has also led to reduced navigations flow mainly due to the stranding of a ship in 1964; e) the lack of political interest in direct investments for the modernization and re-equipment of inland ports network, unsuccessful in relation to maritime and road transport, led finally to an obsolescence situation." All these facts caused the reduction in cargo handling at the Port of Pelotas, leaving many Pelotas factories outside the market, with incompatible forward prices for the domestic market, weakening its economic potential and thus favoring an inertial scenario in the port area.

As claimed Schlee (1993, apud Poetsch, 2002, p. 114), "the Pelotas industrial growth has reached its limit in the 1920s. From the 1930 s on, no major investment was made in order to revive the city's economy, hence the extreme south lost its 'status' of industrial area to the cities of Porto Alegre and Caxias do Sul. The general economic crisis and the effects of the Second World War weakened the whole state economy, and Pelotas, which went through an internal crisis, felt its effects quite incisively."

However, the city of Pelotas has natural peculiarities that stand out in the regional development context, which may attract investment and then resume its stalled economic growth. The Port of Pelotas should be seen as a potential enhancer of economic development of the South Region, since it is located in the 
center of the waterway axis between a major port - the Port of Rio Grande - and a cluster of economic development - the metropolitan region of Porto Alegre and Caxias - in addition to its strategic positioning in MERCOSUL.

Currently most of the economic potential of the Pelotas port area is waiting for investments from the public or private sectors for revitalization. According to Pereira (2000), gradually both the regional business community and the community itself, in order to resume the development of the city, shall come to realize that Pelotas is a channel for the world. The geographical position of such extreme southern area has great importance to the current state development prospects, a fact confirmed by installation of a Naval Cluster in the state of Rio Grande do Sul, more specifically in the city of Rio Grande, neighbor of Pelotas.

Clearly the competitive position of the Port of Pelotas in relation to Rio Grande is not sustainable, given the much better physical and operational conditions of the latter and the small geographic distance between them, combined with the wide availability of ground transportation linking the two urban areas (SEP/PR, 2013). Still, it is prominent to emphasize that the great demand for the naval sector services generated in recent years by the expansion of such industry in the Port of Rio Grande opened the horizon for Pelotas to assist or supplement this port.

Thereby, considering the port system growth, the parallel use of the ports of Pelotas and Rio Grande consists in one of the main alternatives to economic growth in the region, because the proximity of the ports of these cities should not be considered an obstacle to the development of Pelotas; on the contrary, it should be seen as a facilitating factor for a number of motivator activities of the regional economy.

The superintendent of the Port of Rio Grande, Mr. Dirceu Lopes, does not see the port as something apart from the cities that surround it. Actually, one of the purposes is to put Pelotas on the route of the fluvial cargo flow through the Patos and Mirim Lagoons. Lopes also stated that "the port is geographically located in Rio Grande, but it belongs to the whole State. (...) The intention of the superintendence is to operate with the northeast of Uruguay, where there are more than 5 million tons that can be operated by the Port of Rio Grande. And for this to be put in place, the Port of Pelotas will also be used. The municipality will play the role of assisting the Port of Rio Grande in the transport of these cargos." (Revista Visão e Estilo, 2014).

With the support of the Port of Pelotas, the socio-economic potential of the region should be leveraged further, since the municipalities of Santa Vitória do Palmar, São Lourenço do Sul and São José do Norte should also be prepared for new demands and to invest in infrastructure in order to welcome people who come to work in the region. The local governments of the cities that make up the southern region of the State must be engaged to take advantage, as much as possible, of this phase of economic growth, arising from the Naval Cluster of Rio Grande (Revista Visão e Estilo, 2014).

Therefore, the State government should use the natural peculiarities and the potentials of the Port of Pelotas to turn it into an auxiliary port to the Naval Cluster of Rio Grande. The Port of Pelotas should be a storage and distribution center for the coastal shipping and international exportation of rice from the South, among 
other agricultural products and machines, given that small and medium sized importers and exporters have difficulties to operate in large private terminals of the port complex in Rio Grande (Figure 7).

Figure 7. Map showing the Industrial Function of the Port of Pelotas
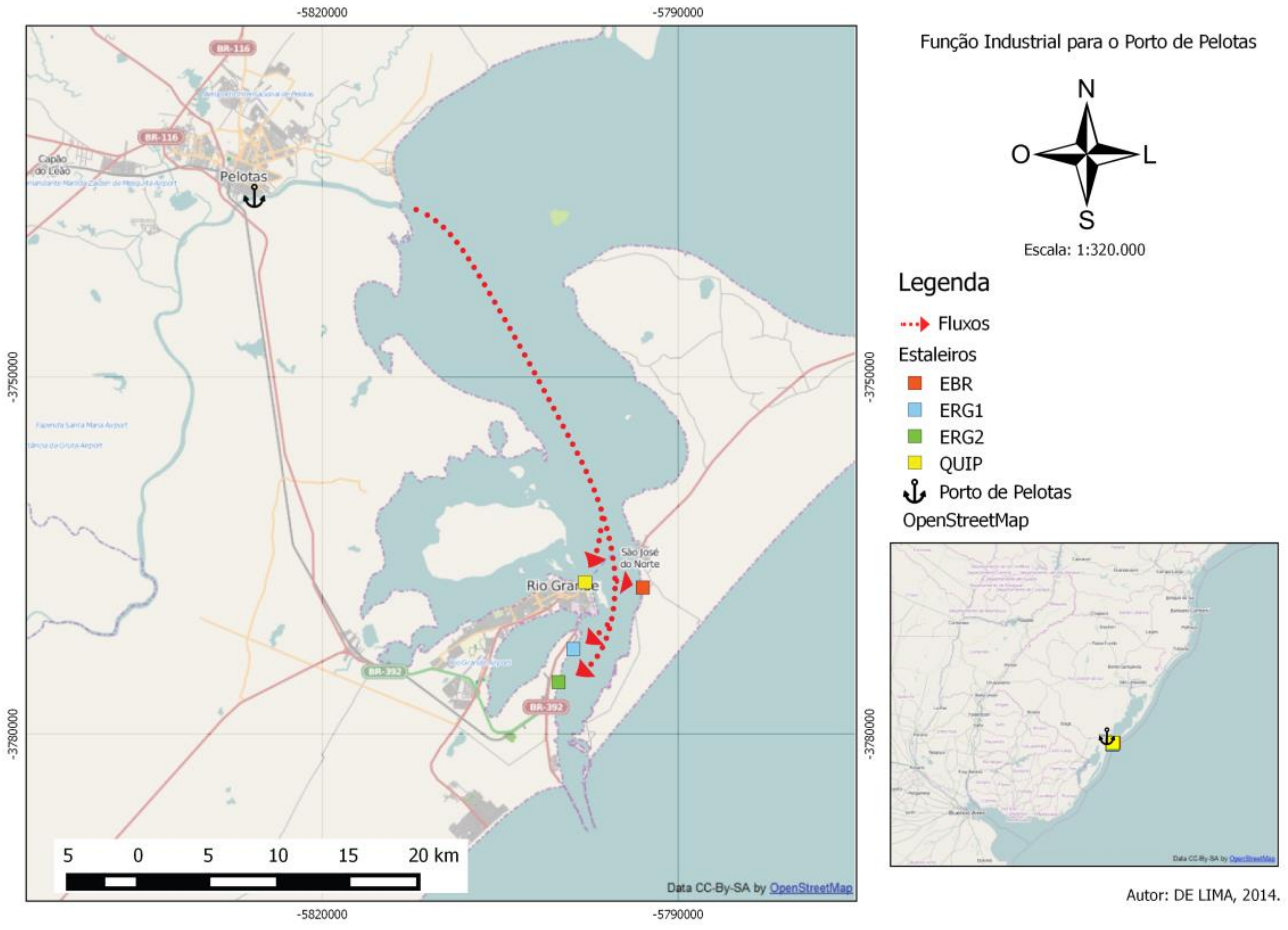

Source: DE LIMA, 2014

Another potential activity for the Port of Pelotas is already in negotiation between the State and Federal governments and the SPH: installing a shipbuilding hub in support of Rio Grande platforms. It is intended that part of the modules of Rio Grande platforms is produced in Pelotas, because there is no more room in Rio Grande for this production.

The Port of Pelotas, in this context, has a significant advantage, despite being near the port complex of Rio Grande, it has idle areas that could be expanded, where industries and/or warehouses could be installed near the docks. These areas could also be addressed to companies dedicated to supporting the activities of the Naval Cluster of Rio Grande, allowing it to act for the purpose it is intended. Some possible locations within the Port of Pelotas are under study for the arrangement of companies such as CIBRAZEM, with 2.343,91 $\mathrm{ft}^{2}$ (7.650 $\left.\mathrm{m}^{2}\right)$; CADEM, with 175.451,74 $\mathrm{ft}^{2}\left(16.300 \mathrm{~m}^{2}\right)$; and the Police Country House, with $10.333 .354 \mathrm{ft}^{2}\left(960.000 \mathrm{~m}^{2}\right)$, all of them owned by the State.

Thus, the Port of Pelotas might act independently, but complementary to the Port of Rio Grande, as a facilitator of load shipping return to Pelotas or as support to the platforms of the Naval Cluster. However, it is known that for this functional alternative to become a reality heavy investments are required for improvements of structural and operational conditions at the Port of Pelotas, such as a deeper draft, buoy age accessibility, appropriate storage, among others. In addition, the Government should take care not to allow the existing competition between the 
cities of Pelotas and Rio Grande - noted in the SWOT matrix- acting as a mediator for the good progress of negotiations.

Social Function

The municipal Master Plan of Pelotas is a legal instrument, established by Law No. 5502, of September 11, 2008, which sets the guidelines, planning and territorial development proposals of the city. According to the Art. 60 of the Plan, part of the port area (the docks) is identified as an Occupied Permanent Preservation Area, i.e. an area whose use and occupation are consolidated, given the social, public and community interest, which can be regulated through mitigatory and compensatory actions, as well as environmental recovery, proportional to the damage and its scale (PELOTAS, 2008).

Moreover, according to Art. 71 of the Master Plan, the port area of Pelotas consists of a "Special Area of Cultural Attraction" (AEIAC-ZPPC), an important historical and cultural city assent (PELOTAS, 2008), showing a uniqueness in the relationship between the built and open environment, perceived through the set of industrial buildings, roads and the port wharf, for the possibility of viewing the open countryside towards the channel and the set of architectural units with recycling potential.

However, the history of the Port development as a neighborhood of Pelotas shows that it did not always have this concern with preserving the port area as a historical and cultural heritage. The economic activities boostering in the port area of Pelotas, a consequence of the port operation between 1940 and 1960, resulted in a unplanned urbanization in this area. The people who worked in the factories and a portion of the low-income population that survived on fishing as well as on cutting and selling reeds - a typical plant of the region (wetlands) - have chosen the port area as a residence and began to occupy it in an unplanned way.

Subsequently, the increase in cargo shipping related to the shipyard and the manufacturing sector in the region resulted in the need to build a larger area for landing and fluvial parking, nowadays called Square, leading to an increased physical and environmental intervention at this location. Actually, the anthropic action on the site generated negative environmental impacts at São Gonçalo Channel, such as the reduction of residual plated, hitherto existing, due to illegal occupation and especially the waste produced by the local population, released directly into the soil or water without prior treatment, which brought irreversible consequences to the environment.

Even with the poor living conditions at the site, the activities related to the channel represented a source of income for the residents, which forced them to withstand adversity, living with various urban problems resulting from lack of adequate territorial planning at this space (Barros et al, 2009).

In addition, around 1960's, the entire port area came under a new process of physical, environmental and socio-economic degradation, a decreased operation activity due to the closure of several factories, which triggered a time of relative stagnation. With the reduction of the port activities and lack of local enforcement, in an uncontrolled manner, without prior planning of use of the area, the community of Doquinhas appeared. The place became home to several families of fishermen, and the impact on ecosystems, already present, got intensified, thus setting up a scenario of environmental, social and economic conflicts. 
This territorial disorganization can be explained for the incompatibility between the two main instruments of territorial planning: the Master Plan and the Port Development and Zoning Plan. According to Kappel (s.a.), the lack of connection between these instruments ultimately characterized the unordered housing and low-income population contingent surrounding the port area, making it difficult to vacate the area towards a more efficient use of it.

Knuth (2013) points out that in 2002, the SIRCHAL seminar addressed the problems of Doquinhas warning to the need of relocating the population out this risk area, although settled since the 1980s. The seminar indicated the space qualification by the Municipal Government for leisure and culture activities. Thus, the port area is today a challenge for managers at different levels of power.

However, a new survival was established in the port area of Pelotas, provided by the Federal University of Pelotas - UFPEL. Glimpsing the possibility of opening its activities, through the plan of Restructuring and Expansion of Federal Universities (REUNI), established by the Ministry of Education and Culture (MEC), the UFPEL resumed the acquisition process of land located between the historic center and the port area of Pelotas. In 2005, the university transferred the Rectory from the city of Capão do Leão to the city of Pelotas, in the building where the old Anglo Slaughterhouse operated, located in the port area of this city, which later became the new Port Campus.

Even though the installation of such UFPEL campus in the port area confirm the disarticulation between the municipal Master Plan and the PDZ of the Port of Pelotas, for Knuth (2013), the presence of UFPEL port Campus is stamping a new face to the local reality, with a new rhythm to daily life and fresh air, both due to the presence of the university community and the economic possibilities offered by the consequent intensification of use of space, thus enhancing the locality.

Poetsch (2002) emphasized the importance of culture in this new century as a factor of production, where the university and research centers, both public and private, are seen as important instruments of social cooperation. As Knuth (2013, p. 19) alleged, "the presence of the Higher Education Institution (IES) inserted in the port region the educational activity, different from the port, industrial and housing uses characteristic of the region. This fact has brought a series of changes to that environment, whose positive and negative aspects imply in socioeconomic, political, institutional relations and the shared use of space".

According to Al-Alam (2011), cited in Knuth (2013), the insertion of UFPEL in the port area provided greater contribution of municipal resources that come to enjoy the place, such as the paving of access roads to the Port Campus, the increase in public transport routes in the area, and the intensification of the city's public safety body activities, favoring the residential use thereof. Thus, with the coming of UFPEL to the port area, this becomes again contemplated by the population, after a long period of helplessness resulting from the relative stagnation of operations at the Port. This movement brings back people to this region. The former river dock, for example, used as parking for small boats - popularly known as Square - came to be appreciated by the community as an outdoor recreational space.

In 2009, the city of Pelotas consolidated a revitalization project in this area aiming at its better use by the population, turning it into a place of social interaction, mainly used by young people and families. Today, many people come to 
the Square in the evening to sip traditional mate and enjoy the sunset behind the bridge over the São Gonçalo Channel, which connects Pelotas to Rio Grande, or amateur fishermen hoist their lines, enjoying a privileged landscape in the city of Pelotas. The site has also served as a stage for artistic events, cultural events and fairs of different kinds.

For the importance of the port area to be safeguarded, the Master Plan has outlined the following guidelines: qualification of the area by enabling access to São Gonçalo Channel; encouraging the recycling of buildings and enhancement of the architectural heritage of the area (Pelotas, 2008).

It is of paramount importance to restore the buildings surrounding the port area of Pelotas, which give life to former cargo storage area. There is a social project estimated to be developed in 2016, envisioned by the Head of the Port of Pelotas - Darci Cunha, named "1st Pier of Songs". The project is intended to cover some of the member countries of MERCOSUL, such as Brazil, Uruguay and Argentina, setting up a music festival with the port as the main theme. "Music brings people together, bringing the youth to socialize, thus socializing the region of the port" (Cunha, 2013).

The accessibility of people to the port is still weak, thus requiring an integration of the port to the community. The opening to population can be done through lectures and invitations to schools, as well as other public and private institutions, to visit the organized port. Aiming at the socialization of the port environment, recently the Port of Pelotas received a group of sailboats, a group of graffiti artists, and artisans through a social project.

According to Professor Paulo Renato Baptista - founder of the Pelotas Maritime Museum Society (SoMMar), in an interview for Diário Popular, there are two projects for the construction of a museum at the Port of Pelotas. He alleges that the possibility of creating a historical space in the Port, with a collection related to its history, that was once used by vessels from different regions of Brazil and the world, is concrete, and one of the projects has already been sent to SPH (Um século, 2014).

It is recommended by government stakeholders to make people feel part of the port as a neighborhood, awakening in them an interest in the resumption of port activities, so that they do not object the improvements to be made in the port area; on the contrary, the intent is to awaken in them the desire for changes that would benefit both port operations and the community in general.

Thus, the hope for revitalization of the port and its cargo storage area is configured by the enhancement of social function in the port area, plus the expected recovery of commercial port function and the possibilities of leveraging industrial and logistic functions. Above all, the city development is expected, in which the social feature must be respected and involved in the planning of the new reality of Pelotas. Therefore, it is essential that port cities have a new perspective on the relationship of the port with its surroundings, aimed at resolving consequent socioeconomic and environmental conflicts of this multifaceted logistics system (Siqueira, 2009).

Scenarios for the Port of Pelotas 
Based on the SWOT matrix and the exposed functions as alternatives to revitalize the Port of Pelotas, three scenarios are now outlined, from the methodology already clarified, as established by Marcial \& Grumbach (2008): an Achievable, a Desirable, and a Possible.

The Achievable scenario refers to the current moment experienced by the Port of Pelotas, characterized by an effort of commercial resumption of its operations, as well as the continuity and intensification of the existing socio-cultural performance. Currently, the Port of Pelotas, besides an incipient social function, plays a shy business function with annual port handling of 400.000 tons, far below of its operational capacity, as shown above (subtitle 4.2, Functional Alternatives to the Port of Pelotas), which can be intensified by means of greater cargo shipping from the entire South Region and Uruguay.

The massification of cargo shipping at the Port of Pelotas and an improvement in social function shall promote the Port of Pelotas from the current scenario - Achievable - to the Desirable scenario, characterized by potentiation of the two existing features - commercial and social. In addition, other two functions should be assumed: the logistics function, which is well underway, through the project of Brazil-Uruguay Waterway; and the industrial function, made possible by the reality of the naval industry located in the city of Rio Grande, which generates the aspiration of the Port of Pelotas to act complementarily to such port complex.

With the commercial function intensification of the Port of Pelotas, made possible due to the logistic function implementation, assuming an initial load motion of approximately 2 million tons from the Rio Grande do Sul (wood: 1.200.000t; gravel: 250.000t; soy: 80.000t; rice: 480.000t; containerized cargo: 58.700t; malt: 100.000t), plus an estimate of 2,6 million tons from Uruguay (agriculture bulks: 2.533.918t; industrialized wood: 60.142t; cement: 41.869t), totalizing almost 5.000.000t. Shipping beyond 2020 would multiply by almost 12 times (5.000.000 / 400.000) concerning the total amount currently operated.

Finally, another scenario foreseen for the Port of Pelotas is the Possible one, characterized by the maximum functionalization of this port, which brings out the best it can offer in terms of operation. In a time frame of five years, from 2020 to 2025, it could operate over 10 million tons of cargo shipping, represented by an increase of $2.500 \%(10.000 .000 * 100) / 400.000)$ compared to the current total amount. This scenario is characterized by fostering the four functions previously established in the scenarios set for the port of Pelotas.

It is important to emphasize the possibility of confusion between the Desirable and the Possible scenarios, as in the case of this study the four features that make up the Possible scenario comes to be at the same time the Desirable scenario, as such functional typologies are desirable and become feasible in a slightly wider interval, thus simultaneously setting the Possible and Desirable scenarios. After all, reality shows a Naval Cluster located in the nearby city, which may attract industries to the Port of Pelotas, and a bi-national waterway under implementation. Thus, the Desirable scenario may become Possible within a larger time period.

Therefore, the Port of Pelotas shows an effective potential for the revitalization of its current activities and the performance of additional and 
supplementary functions. It is very possible that it shall play an important role to promote local and regional economy.

\section{Conclusion}

A port is not only a point of product flow. Its importance goes beyond the exchange of goods with added values. It has countless riches in various forms which amalgamate with other cultures from different peoples and nations. A port means a cultural exchange link. Moreover, it enables linked services and consequently direct and indirect jobs, as well as revenue through the payment of taxes. Therefore, the port performance does not take place through financial results only, but also the social, cultural and technological results, and other environments that make up the port system (Porto, 2007).

It is an activity that should be assessed in all its connections to development, which gain new dimensions over time and should be included in the port planning. Finally, the port not only transforms the present, but also determines the future (Porto, 2007).

The aim of this study - to propose prospective scenarios for the revitalization of the Port of Pelotas - was fully achieved from the SWOT analysis of the current situation of the Port as well as from the functional alternatives brought to discussion. SWOT analysis showed the immediate operational possibilities, pointing out deficiencies and highlighting strengths in order to improve the latter and rectify the former.

The four functional alternatives presented herein - commercial, logistics, industrial and social - showed the possibilities for the Port of Pelotas to operate again and also carry significant share of the economic results of the South Region. The following alternatives were proposed to boost its current drive: integrating it to the route of river cargo shipping from the metropolitan and mountainous region of the State, in addition to cargo from Uruguay, in a complementary way to the Port of Rio Grande, through the full recovery of waterway transport and actualization of the Brazil-Uruguay Waterway; setting it up as a new support center Rio Grande's Naval Cluster; as well as consolidating as a social space for culture and leisure to the local community.

As a result, three (3) scenarios were outlined for the Port of Pelotas. The first one - Achievable - is consistent with its current operational status, considering the possibility of maximizing ongoing commercial and social functions. The second one - Desirable - adds two other features to the Port of Pelotas, the logistics and industrial functions. The third and final scenario proposed - Possible - suggests a full implementation in order to enhance the four previously structured functions, thus reaching the utmost functionality.

It follows therefore that the Port of Pelotas, despite its current relative economic and functional stagnation, due to several factors of economic and political nature, is in a position to play a new and important role in the economic development recovery of the south of the State of Rio Grande do Sul, as well as in the integrated development of the Mirim Lagoon Basin through the bi-national Brazil-Uruguay waterway. 


\section{REFERENCES}

ANTAQ. Agência Nacional de Transportes Aquaviários. O porto verde: modelo ambiental portuário. Brasília: ANTAQ, 2011. Disponível em:

<http://www.antaq.gov.br/Portal/pdf/PortoVerde.pdf>. Acesso em: 19 out. 2013.

ANTAQ. Portal da Agência Nacional de Transportes Aquaviários. Disponível em: <www.antaq.gov.br/>. Acesso em: 09 out. 2012.

BARROS, LândersonAntória; LIHTNOV, Dione Dutra; VIEIRA, Sidney Gonçalves. Contextualização Histórica na Formação do Bairro Porto de Pelotas e os Problemas Urbano-Ambientais no Loteamento das Doquinhas. In: XVIII CIC, XI ENPOS e I MOSTRA CIENTÍFICA UFPel, Anais...Pelotas, 2009. Disponível em: <http://www.ufpel.edu.br/cic/2009/cd/pdf/CH/CH_01951.pdf >. Acesso em: 22 jul. 2013.

CAMPÊLO, Manoel Ramalho; DUHÁ, Paulo Antonio Dutra. Navegação: a história do transporte hidroviário interior do Rio Grande do Sul. Porto Alegre: Centhury, 2009.

CRUZ, Carlos. A análise SWOT como ferramenta de gestão estratégica. 2010. Disponível em <http://www.superempreendedores.com/empreendedorismo/aanalise-swot-como-ferramenta-de-gestao-estrategica>. Acesso em: 08 out. 2012.

CUNHA, Darci José Martins. Chefe de Divisão do Porto de Pelotas. Entrevista concedida à dissertação em 06 dez. 2013.

EMBRAPA - Empresa Brasileira de Pesquisa Agropecuária. Quando a cevada é a escolha certa. Notícia $n^{\circ}$ 36/2012, 27/06/12. Disponível em:

<www.cnpt.embrapa.br/noticias/2012/not1236.htm>. Acesso em: 10 dez. 2012.

FOSSATI, Cástulo Eizmendi. Metodologia para a Prospecção de Cenários Relacionados à Construção dos Portos Uruguaios na Região da Lagoa Mirim. Rio Grande, 2013.

GIL, Antonio Carlos. Como elaborar projetos de pesquisa. 4. ed. São Paulo: Atlas, 2002.

HOYLE, B. S. \& HILLING, D. Seaport systems and spatial change.Technology, industry and development strategies.Chichester, John Willey \& Sons, 1984.

IRGA - Instituto Rio Grandense do Arroz. Produção, Produtividade do Arroz - RS x BR. Disponível em: <http://www.irga.rs.gov.br/conteudo/4215/safras>. Acesso em: 22 dez. 2013.

KAPPEL, Raimundo, F. Portos brasileiros: novo desafio para a sociedade. Disponível em: 
<http://www.sbpcnet.org.br/livro/57ra/programas/conf_simp/textos/raimundokapp el.htm>. Acesso em: 22 fev. 2013.

KNUTH, Franco Goulart. Os conflitos de uso da zona portuária de Pelotas e uma proposta de estrutura de negociação na perspectiva do Gerenciamento Costeiro Integrado. Rio Grande: FURG, 2013.

MARCIAL, Eliane Coutinho; GRUMBACH, Raul José dos Santos. Cenários Prospectivos: como construir um futuro melhor. 5. ed. Rio de Janeiro: Editora FGV, 2008.

PELOTAS, Lei ${ }^{\circ} 5.502$, de 11 de setembro de 2008. Institui o Plano Diretor Municipal e estabelece as diretrizes e proposições de ordenamento e desenvolvimento territorial no Município de Pelotas, e dá outras providências. Disponível em: <http://www.pelotas.com.br/politica_urbana_ambiental/planejamento_urbano/III_p lano_diretor/lei_iii_plano_diretor/arquivos/lei__5502.pdf>. Acesso em: $19 \overline{9}$ dez. 2012.

PEREIRA, Clésis Niara Luna. O processo de desativação do Porto de Pelotas/RS: uma alternativa para viabilizar a sua reativação. Pelotas: UFPel, 2000.

POETSCH, Martha Costa. Área Portuária de Pelotas e sua Identidade. Pelotas: UFPel, 2002.

PORTO, Marcos Maia. Portos e o Desenvolvimento. São Paulo: Aduaneira, 2007.

PORTO, Marcos Maia; TEIXEIRA, Sérgio Grein. Portos e Meio Ambiente. São Paulo: Aduaneiras, 2002.

REVISTA VISÃO E ESTILO. Pelotas na rota. 2. ed. dez./2013 e jan./2014.

ROESCH, S. M. A. Projetos de Estágio e de Pesquisa em Administração. 3 ed. São Paulo: Atlas, 2009.

SEP/PR - Secretaria de Portos da Presidência da República. Plano Mestre: Porto de Pelotas. Florianópolis, 2013.

SEVERINO, Antônio Joaquim. Metodologia do Trabalho Científico. 23 ed. São Paulo: Cortez, 2007.

SIQUEIRA, A. S. Gestão ambiental nas cidades-porto: o caso de Santos. In: XII EGAL ENCONTRO DE GEÓGRAFOS DA AMÉRICA LATINA. Anais...2009. Disponível em <http://egal2009.easyplanners.info/area01/1184_Santos_Siqueira_Alexsandro.pdf> Acesso em: 14 mai. 2013.

SOUZA, Marcelo Lopes de. Mudar a cidade: uma introdução crítica ao planejamento e à gestão urbanos. 3. ed. Rio de Janeiro: Bertrand Brasil, 2004. 
SPH. Superintendência de Portos e Hidrovias. Disponível em: <http://www.sph.rs.gov.br/>. Acesso em: 02 out. 2012.

SPH/ PELOTAS. Superintendência de Portos e Hidrovias. Divisão do Porto de Pelotas. 2016.

UM SÉCULO de história atracado no Porto. Diário Popular. Pelotas, p. 2-3, 16 mar. 2014.

UNCTAD (2014). Review of maritime transport - 2014. New York, United Nations, UNCTAD.

Marcelo Vinícius de la Rocha Domingues. Professor na Universidade Federal do Rio Grande - FURG. mavidlrd@terra.com.br

Letícia de Magalhães Bandeira. FURG. lelebandeira@gmail.com 